\title{
RUSSIAN RESPONSE TO THE SPREAD OF THE COVID-19 PANDEMIC: FEDERAL LEGISLATION AND HUMAN RIGHTS WITHIN SELF- ISOLATION AND QUARANTINE
}

\author{
Anastasia Belousova ${ }^{1 *}$, Alexander Belousov ${ }^{2}$ \\ ${ }^{1}$ Associate professor, PhD in Laws, RUDN University, RUSSIAN FEDERATION, \\ belousova.rudn@gmail.com \\ ${ }^{2}$ Full Professor, Dr.Sc. in History, RUDN University, RUSSIAN FEDERATION, \\ belousov-aa@rudn.ru \\ ${ }^{*}$ Corresponding Author
}

\begin{abstract}
The purpose of the article is to explore the new Russian Federation legislation and its implementation within comprehensive measures of the State response to the spread of the new coronavirus infection (COVID-19).

The rationale for the research incorporates international, regional, and national law doctrines on human rights.

The research aims to consider Russian federal legislation response to the spread of the COVID-19 Pandemic from the angle of human rights provision within self-isolation and quarantine regimes.

The research sets forth the hypothesis that the human rights provision in times of pandemics and health emergencies sharpens an acute nature of question on balance between individual and community rights protection during coronavirus world -wide spread.

The above hypothesis determines a number of research tasks. They are supposed to specify the latest amendments to national legislation branches, explore its implementation with regard to various populations who stay in the country, and consider the individual and collective human rights protection and provision during self-isolation and quarantine regimes.

The research materials include decisions, comments and clarifications of the Russian courts of various jurisdictions, with regard to the implementation of legislative changes and measures aimed at counteracting the spread of the new coronavirus infection (COVID-19) in the Russian Federation,

The research methodology is based on a comprehensive comparative analysis of Russian legislation, its law enforcement practice during the COVD 19 pandemic. The methods of analysis and synthesis, interpretation of legislation, and case -analysis have been applied. The selection and investigation of cases rests on fieldbased approach, content analysis and coding techniques.

The results of the study make it possible to highlight challenges and solutions to the goal of ensuring the rule of law and human rights through the major legislative branches of the Russian Federation. The data shows that Russian courts combine background legislation and latest regulations to consider cases within particular contexts, with regard to concrete, individuals, motives, needs, and deeds. Meanwhile, civil society provides a critical analysis of the situation and mentioned lack of balance between individual and collective rights assurance.
\end{abstract}

Keywords: Law, jurisprudence, human rights, emergencies, pandemic. 


\section{INTRODUCTION}

The COVID 19 produced a crucial impact on the discussion on human rights within international (COVID-19 and Human Rights, 2020), regional (The impact of the COVID-19 pandemic on human rights and the rule of law - Our action, 2020), and national legislations, as well.

Academia has laid specific emphasis on the theory of human rights and challenges to their limitation during self- isolation and quarantine regimes (Atabekova, 2020, Botes, Thaldar, 2020, Parmet, Sinha, 2020). Researchers try to find the answer to the question if isolation and quarantine were draconian measures or proportional response (Moodley et al., 2020).

The present research follows field-based research trend and considers it relevant to explore particular cases within particular national legislation. The authors' affiliation argues for the consideration of their national legal environment, namely that of the Russian Federation.

The research sets forth the hypothesis that the human rights provision in times of pandemics and health emergencies sharpens an acute nature of question on balance between individual and community rights protection during coronavirus world -wide spread.

The research goal is to consider Russian federal legislation response to the spread of the COVID-19 Pandemic from the angle of human rights provision.

The above goal shapes the following research questions

- What is the legal framework for self-isolation and quarantine in Russia?

- What are jurisdictions in force for liability and penalties related to breach of self-isolation and quarantine in Russia?

- How does legislation work in judicial practice?

\section{METHODOLOGY}

The research methodology integrated relevant literature analysis to introduce the nature of the topic under study within international landscape.

The study follows the principles of content-based analysis of legislation under investigation and the use of the coding techniques for the legal texts sorting (Atabekova, 2019) to explore issues of law enforcement practice during COVD 19 self-isolation and quarantine pandemic with regard to balance between individual and collective human rights

The methods of analysis and synthesis, interpretation of legislation have been applied.

The empirical investigation followed

The digital legal bases of garant.ru and consultant.ru were used for selection of primary sources. They included decisions of courts within administrative jurisdictions, commentaries of the Supreme Court on the distinction between administrative and criminal jurisdictions with regard to the topic under study, data from the official mass media.

Case study techniques were applied to the sources investigation as this research tool proved its relevance within different legal contexts (Atabekova, 2017).

\section{RESULTS AND DISCUSSION}

\subsection{Legal Framework for Self-Isolation and Quarantine in Russia}

Self- isolation and quarantine were crucial measures to counter the pandemic spread in Russia.

However, there were cases when both foreign and Russian citizens broke the legal norms of Russia as the country of their stay.

It should be noted that the Russian legislation provide distinction between quarantine and self-isolation. In the case of "COVID-2019", quarantine is applied to all Russians who have arrived from abroad and people living with them, as well as those who have unconfirmed symptoms of coronavirus, who have been in contact with a patient with coronavirus infection and who are allowed to be treated at home, the rest of the citizens are prescribed self-isolation mode. Self-isolation mode involves a stay at home, while a person avoids 
contact with other people.

Unlike quarantine, within the self-isolation mode it is allowed to leave the apartment in exceptional cases. Each Russian region itself determines the reasons for which residents can leave their homes, as well as the rules for such exits. Typically, these reasons include such points as seeking emergency medical help, going to the nearest grocery store or pharmacy, walking the dog, and going to work in case it is really necessary. Self-isolation is part of the high alert regime. Both quarantine and self-isolation are restrictive, but imply different degrees of responsibility for violation of the established regime.

As far as the self-isolation mode is concerned it is subject to regulation under Resolution No 7 of the Chief State Sanitary Doctor of the Russian Federation (2020). This resolution applies to foreign citizens and stateless persons, citizens of the Russian Federation arriving in the territory of the Russian Federation across the state border, employers, heads of executive bodies of the constituent entities of the Russian Federation in the field of health protection. The breach of the resolution provisions are considered in line with the Russian Code on Administrative offences (2001/2020) (Shuvalova, 2020).

\subsection{Jurisdictions for Liability and Penalties in Russia}

The Supreme Court of the Russian federation in its Review N2 of the Supreme Court of the Russian on selected issues of judicial practice, related to the application of legislation and countermeasures to the spread new coronavirus infection (COVID-19) on the territory of the Russian Federation (2020) provided a clear distinction between administrative and criminal jurisdiction implementation with regard to violation of self-isolation and quarantine.

Violators of the general regime of self-isolation can be brought under Part 1 of Article 19.3 of the Russian Code on Administrative Offences. In this case, a fine from five hundred to one thousand rubles or up to 15 days of administrative arrest is imposed.

Those who decide to walk to a distant grocery store risk being punished. As for organizations that have not stopped working, despite the restrictions, officials will be required to pay from 30 to 40 thousand rubles, and legal entities - from 200 to 300 thousand. The most stringent measures have been established against quarantine violators. So, for using transport is punished with a fine of 4-5 thousand rubles. A repeated violation will entail a fine of five thousand rubles for citizens, from 40 to 50 thousand for officials and from 300 to 500 thousand for legal entities.

If a person infected with COVID-19 en masse infects other people, in this case he/she faces punishment under the criminal law, i.e. imprisonment for up to two years or a fine of 500 to 700 thousand rubbles. If the infection leads to the death of one person - imprisonment from three to five years or a fine of one to two million rubles. For the death of two or more people, the penalty is from five to seven years in prison, under art 236 of the Criminal Code of the Russian Federation (1996), see also other explanation in the official mass media (What is difference...2020).

Thus, liability and punishment are exercise within administrative and criminal jurisdictions in the Russian Federation.

\subsection{Judicial Practice: Case Studies}

The present section considers judicial practice on administrative offences and their punishment with respect to individuals.

A number of cases are set forth as examples of judicial practice with regard to Russian and foreign citizens.

The first case reveals that when a Russian citizen's compliance with the self-isolation regime being checked, it was found that the citizen was not at his place of residence, thereby violating the conditions of the order of the chief state sanitary doctor which was handed over to him. The order prescribed that the citizen should be at the place of residence in isolation and not leave it for 14 days. The court (Case N 5-133 / 2020) found him guilty of committing an administrative offense under Part 2 of Art. 6.3 of the e Russian Federation Code on Administrative Offences, and imposed a punishment in the form of an administrative fine in the amount of 15,000 rubbles.

The second example shows that in case of violations absence the Court can terminate the case.

During the self-isolation regime in force a female citizen was on the street (in a public place), with no exceptional reasons for being in a public place. It was reliably established and she did not dispute that she left the place of residence without the goals specified in the decree of the Government of the Kaliningrad 
Region which announce the above reasons. The woman explained that she went out into the street in order to breathe air, take a walk. The court indicated that the woman did not refer to the citizens who have arrived in Russia from a state epidemiologically unfavourable coronavirus infection. Nor she was in contact with the source of the disease or in contact with persons with suspicion of the disease an infectious. The woman did not belong to those who evaded treatment of a dangerous infectious disease, violated the sanitary and epidemiological regime, as well as to those who failed to comply with a legal order or a requirement of an authority. Under such circumstances, the court concluded that the actions of the citizen did not contain an administrative offense under Part 2 of Art. 6.3 of the Russian Federation Code of Administrative Offenses and terminated the proceedings under part 2 of Art. 6.3 of the Code, in the absence of an administrative offense (Case N 5-36 / 2020).

The third case seems relevant as it considers the right of a citizen of the Russian Federation to freedom of movement.

The applicant filed a complaint against the government of Bryansk region decision to introduce a high alert regime and introduce limits to the freedom of movement without emergency reasons and special needs related to work activities.

To start with, we should underline that in accordance with par 3 of Art. 55 of the Constitution of the Russian Federation, this right may be limited by federal law to the relevant extent in cases which refer to the protection of health, rights and legitimate interests of others (The Constitution of the Russian Federation 1993/2020). Specifying these prescriptions, Art. 8 of the Law of the Russian Federation Law N 5242-I (1993) establishes an exhaustive list of grounds for restricting the right of citizens of the Russian Federation to freedom of movement, choice of place of stay and residence within the Russian Federation in accordance with the laws of the Russian Federation.

This article provides for the possibility of limiting these rights. It can be done not only in the territory where the state of emergency has been declared, but also in certain territories and in settlements where, due to the danger of the spread of infectious and mass non-infectious diseases and human poisoning, special conditions and modes of residence of the population and economic activity have been announced.

Taking into account the above norms, the court of the Bryansk region decided that the regional government had lawfully introduced a high alert regime on the territory of the Bryansk region, which meant certain limitations to the freedom of movement as the respective right is not absolute (Case No. 3a-722/2020 , 2020).

A number of claims were submitted by Russian citizens to local courts with regard to personal data confidentiality issues in the course of the digital pass arrangement during the quarantine and self-isolation period. The procedure included the obligation of citizens to provide personal data, contact phone number, goals and route of travel through the use of the SMS portal or the telephone line of the Unified Information Service of the Government of Moscow.

In reply to the contested requirements, the Moscow City Court decided that The contested provisions do not restrict privacy, violate personal and family secrets, protection of honour and good name; do not contain statements providing for the collection, storage, use and dissemination of information about a person's private life without his/her consent; do not contain provisions limiting the choice of citizens to place of residence and residence (Case No. 3a-3877/2020, 2020).

We consider relevant to explore cases which involved foreign citizens, as well.

First we have to mention that due to the threat of spread of a new COVID 19 infection, which poses a danger to others, in accordance with the requirements of paragraph 6 of part 1 of Art. 51 of the Federal Law No. 52FZ (1999), the Chief State Sanitary Doctor of the Russian Federation on January 31, 2020 issued Resolution No. 3 (2020). Its clause 1.4 provides for the need to ensure continuous medical supervision for a period of 14 calendar days of Chinese citizens holding a residence permit in the Russian Federation, upon their return from the Popular Republic of China (PRC). If such Chinese citizens develop symptoms that do not exclude a new coronavirus infection, the relevant healthcare service agencies conduct their isolation and laboratory examination.

However, a citizen of the PRC, who was handed a decree by the Chief State Sanitary Doctor for Moscow on the need to maintain self- isolation period for 14 days under medical supervision at the place of residence, left the place of residence before the expiration of 14 day period of isolation, thereby committing an administrative offense under Part 3 of Art. 18.8 of the Code on Administrative Offences of the Russian Federation. Decision of the Moscow City Court (Case N 7-3427 / 2020 ) says that any references to the 
situation of extreme necessity should be rejected as untenable, since the offense by the applicant was not committed by force of emergency, but as a result of her violation of the regime of stay in the Russian Federation.

The next two cases refer to the challenges related to the expiration of residence permit or visa valid period.

A citizen of Tajikistan was issued a temporary residence permit, which was cancelled in court, after which he was obliged to leave the territory of the Russian Federation, but he did not. The person explained that he could not leave the Russian Federation, since the family was in a difficult financial situation, and he could not buy air tickets for all family members and organize a move to the Republic of Tajikistan.

In the spring, he intended to leave, but the coronavirus pandemic began and the Russian Federation completely closed its borders, and from 30.03.2020 he and his family, given the presence of a young child, could not leave the Russian Federation. After the opening of the borders and the resumption of air communication with the Republic of Tajikistan, he and his family intend to voluntarily leave the Russian Federation. He asked not to impose punishment associated with forced expulsion from the Russian Federation, since he intends to leave on a voluntary basis. The court found him guilty of committing an administrative offense under Part 1.1 of Art. 18.8 of the Russian Federation Code on Administrative Offenses, and imposed a punishment in the form of an administrative fine in the amount of 2,000 rubles, without imposing a penalty in the form of administrative expulsion from the Russian Federation (Case N 5-82 / 2020)

The next case considers visa valid period expiration. A citizen of the Democratic People's Republic of Korea (DPRK) was issued a visa to stay in the Russian Federation for study. When the visa valid period expired. He took measures to timely return to the home country. However, due to reasons beyond his control (the ban on the entry of all international vehicles into the DPRK in order to prevent the spread of coronavirus infection), he could not leave the territory of the Russian Federation.

A foreign citizen also applied to the territorial office of the Ministry of Internal Affairs of Russia to extend the validity of a visa and pay the required a state fee for extending the validity of a visa. In such circumstances, the regional court concluded that there was no guilt in his actions in committing an offense under Part 1.1 of Art. 18.8 of the Code on Administrative Offences of the Russian Federation (Violation by a foreign citizen or stateless person of the rules of entry into the Russian Federation or the regime of stay (residence) in the Russian Federation).

The decision of the Irkutsk Regional Court (Case N 7-94 / 2020) terminated the proceedings in the case due to the lack of an administrative offense and released the foreign citizen from the Center for the temporary detention of foreign citizens.

Each legal research obtains additional value when opposing analytical opinions are considered. The above cases can be supplemented by brief profile of the civil society vision of the situation with legislation and human rights during the COVID 19.

Civil society argues that a significant number of applications were received from citizens who received administrative fines based on the data of the Social Monitoring mobile application. In addition, the media widely covered the cases of charging fines for leaving the place of residence to persons unable to move independently due to disability. A significant amount of complaints was also received about the unjustified accrual of fines by the vehicle number by video cameras, due to the cancellation of a previously issued digital pass to work mistakes made in its registration. It should be noted that the legislation on administrative offenses provides an exhaustive list of administrative offenses that can be recorded by means of autonomously working video cameras. Cases of violation of self-isolation are not included in this list.

Taking into account the above, Chairman of the Council under the President of the Russian Federation for the development of civil society and human rights proposed to cancel out not only those fines that were charged as a result of failures of the Social Monitoring application, but also all other fines for violation of selfisolation, if these cases did not entail negative consequences (for example, as a result of unauthorized leaving the place of residence, another person was infected). If the purpose of the introduction of fines was to reduce cases of violation of self-isolation, then their cancellation will not affect this goal in any way.

From a legal point of view, the abolition of fines can be carried out by the issuance of an act on administrative amnesty by the State Duma of the Federal Assembly of the Russian Federation. Such an amnesty has no precedents in Russian history however; it fully complies with the Constitution of the Russian Federation and does not contradict administrative legislation (Report ...2020). 


\section{CONCLUSIONS}

The research findings confirm the hypothesis that argued that the human rights provision in times of pandemics and health emergencies sharpens an acute nature of question on balance between individual and community rights protection during coronavirus world -wide spread.

The investigation has made it possible to reach the research goal and provided concrete facts related to Russian federal legislation response to the spread of the COVID-19 Pandemic from the angle of human rights provision.

The study outlined the legal framework for self-isolation and quarantine in Russia, specified jurisdictions in force for liability and penalties related to breach of self-isolation and quarantine in Russia, revealed the legislation implementation in judicial practice?

The cases confirm that both the background administrative legislation and latest regulations to counter the COVID 19 spread provide legal framework for various decisions in line with particular legal contexts. Moreover, court decisions which impose administrative punishment on Russian and foreign citizens who have broken the legislation in force, strive to protect the human rights of other community representatives in terms of their right to health services and protection as one of the fundamental human rights fixed in international, and regional legislation across the world.

Freedom of movement and choice of place of residence are among the fundamental civil rights. However, where there are rights, there are responsibilities. In a situation of a coronavirus epidemic, it is also about adhering to the rules of staying with society and the rules of hygiene.

Obviously, during a pandemic, states will have to restrict their own citizens in some way, while all restrictions can certainly only be temporary.

Due to the fact that the virus is spreading quickly and its properties are poorly understood, states are forced to tighten control over citizens. Quarantine reduces social contact to a minimum, thus helping to keep hospitals from overcrowding and increasing the chances of people not being infected or surviving. Therefore, special measures are needed. Their observance is a matter of civic consciousness of members of society.

\section{REFERENCE LIST}

Atabekova, A. (2019). Do Discourse Studies Matter with Regard to Protect Minors against Violence in Sport? Proceedings of INTCESS 2019- 6th International Conference on Education and Social Sciences, 1190-1194.

Atabekova, A. (2017). ICT-based Visualization for Language and Culture Mediation Skills Training: Addressing Societal Needs. Procedia Social and Behavioral Sciences, volume 237, 209-215.

Atabekova, A. (2020). University discourse to foster youth's sustainability in society amidst COVID19: International and Russian Features. Sustainability, 12(18), 7336.

Botes, W. M., \& Thaldar, D. W. (2020). COVID-19 and quarantine orders: A practical approach. SAMJ: South African Medical Journal, 110(6), 1-4. doi:10.7196/SAMJ.2020.v110i6.14794

Case N 5-133 / 2020, decision of the Morshansk District Court of the Tambov Region (2020, April 24), https://demo.garant.ru/services/arbitr/link/313617079

Case N 5-36 / 2020, decision of the Zelenogradskiy District Court of the Kaliningrad Region ( 2020, April 28) https://demo.garant.ru/services/arbitr/link/313621798

Case N 5-82 / 2020, decision of the Norilsk City Court of the Krasnoyarsk Territory ( 2020, April 17) https://demo.garant.ru/services/arbitr/link/313547427

Case N 7-3427 / 2020, decision of the Moscow City Court ( 2020, March 12), https://demo.garant.ru/\#/document/313124000/entry/0

Case N 7-94 / 2020, decision of the Irkutsk Regional Court in (2020, March 31), https://demo.garant.ru/services/arbitr/link/313501936

Case No. 3a-3877/2020, decision of the Moscow City Court (2020, April 28) 
https://demo.garant.ru/\#/document/31365976/entry/0

Case No. 3a-722/2020, decision of the Bryansk Regional Court (2020, April 10). https://demo.garant.ru/\#/document/313470521/entry/0

COVID-19 and Human Rights. (2020, April). United Nations. https://www.un.org/victimsofterrorism/sites/www.un.org.victimsofterrorism/files/un__human_rights_and_covid_april_2020.pdf

Federal Law of March 30, 1999 No. 52-FZ "On the Sanitary and Epidemiological Welfare of the Population" ( 1999, March 30) http://base.garant.ru/12115118/

Law N 5242-I "On the right of citizens of the Russian Federation to freedom of movement, choice of place of stay and residence within the Russian Federation" ( 1993, June 25). http://www.consultant.ru/document/cons_doc_LAW_2255/

Moodley, K., Obasa, A. E., \& London, L. (2020). Isolation and quarantine in South Africa during COVID-19: Draconian measures or proportional response? SAMJ: South African Medical Journal, 110(6), 1-2. doi:10.7196/SAMJ.2020.v110i6.1484

Parmet, W. E., \& Sinha, M. S. (2020). Covid-19-the law and limits of quarantine. New England Journal of Medicine, 382(15), e28.doi: 10.1056/NEJMp2004211

Report of the Council under the President of the Russian Federation for the development of civil society and human rights on the topic "Lessons from the epidemic from the point of view of observance of human and civil rights and freedoms" (2020). http://president-sovet.ru/documents/read/687/

Resolution No 7 of the Chief State Sanitary Doctor of the Russian Federation of "On ensuring isolation in order to prevent the spread of COVID-2019" (2020, March 18). http://base.garant.ru/73764449/

Resolution of the Chief State Sanitary Doctor of the Russian Federation No. 3 "On additional sanitary and anti-epidemic (preventive) measures to prevent the import and spread of a new coronavirus infection caused by 2019-nCoV (2020, January 31). http://www.garant.ru/hotlaw/federal/1325308/

Review N2 of the Supreme Court of the Russian on selected issues of judicial practice, related to the application of legislation and countermeasures to the spread new coronavirus infection (COVID-19) on the territory of the Russian Federation (2020,April 30) https://vsrf.ru/documents/thematics/28882/

Russian Federation Code on Administrative Offences (2001/2020) http://base.garant.ru/12125267/

Russian Federation Criminal Code N 63 FZ (1996). http://www.consultant.ru/document/cons_doc_LAW_10699/

Shuvalova, M.(2020, March 26). Self-isolation in connection with the coronavirus: who is obliged to comply with the regime and what threats its violation brings. http://www.garant.ru/article/1333919/

Supreme Court of the Russian Federation (2020, April 30). https://vsrf.ru/documents/thematics/28882/

The Constitution of the Russian Federation (1993/2020). http://www.consultant.ru/document/cons_doc_LAW_28399/

The impact of the COVID-19 pandemic on human rights and the rule of law - Our action (2020). Council of Europe. https://www.coe.int/en/web/human-rights-rule-of-law/covid19

What is the difference between quarantine and self-isolation from a legal point of view ( 2020, April 9). https://ria.ru/20200409/1569804242.html 